\title{
Professor R. C. Punnett
}

DROFESSOR Punnett died on Jan. 3rd, 1967, at the age of 91. From 1904, when he joined forces with William Bateson, he was interested all his life in heredity in poultry, and made many important contributions to knowledege of that subject. It seems appropriate, therefore, to record in the pages of this journal something about his accomplishments.

Reginald Crundall Punnett was born at Tonbridge, in Kent, on June 20th, 1875. As a student at Cambridge University, he became interested in zoology,

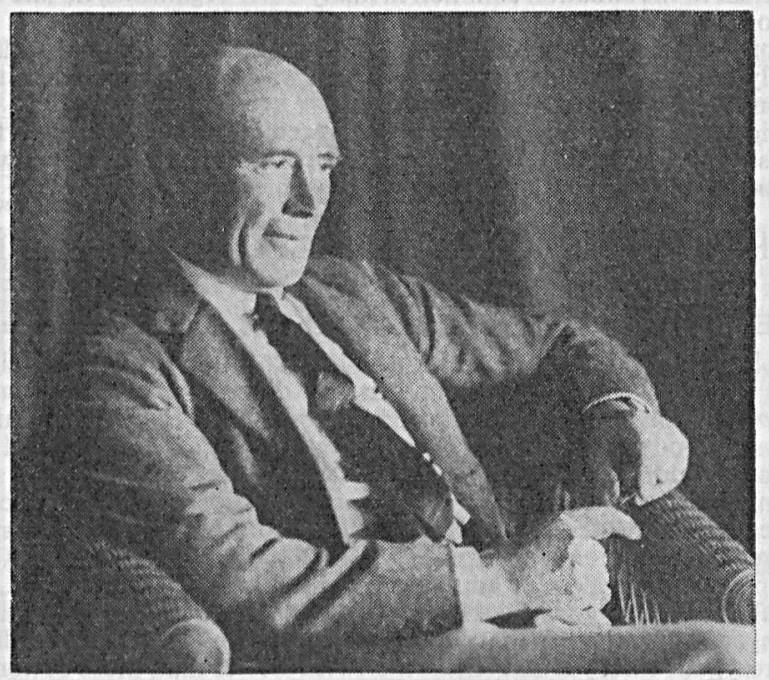

especially in the classification of nemertine worms and in the anatomy of those worms and of certain small sharks.

His innate ability was soon recognised and, at a time when grants-in-aid were much harder for students to get than they are now, he managed to find financial support for brief periods of study in marine biological laboratories at Plymouth, Naples and Bergen.

After qualifying with flying colours at Cambridge, he spent three years as an instructor in zoology at St. Andrews University, but returned to Cambridge in 1902. Starting as demonstrator in morphology, he became successively Balfour Student in Zoology, superintendent of the Museum of Zoology, professor of biology and (in 1912) the first Arthur Balfour Professor of Genetics. He was elected in 1912 a fellow of the Royal Society of London and, ten years later, was awarded that society's Darwin medal.

For a full record of Punnett's early career as a zoologist, readers should see the fascinating account written by Crew.

The steps by which Punnett became interested in poultry are interesting. Not long after his return to Cambridge in 1902, he undertook some experiments to determine whether or not the sex-ratio in mice could be influenced by the diet. It occurred to him that his proposed tests might be so designed that they would also yield some information about the inheritance of coat colour in mice, and, to that end, wrote to Bateson, whom he knew to be studying heredity in other species.

In 1903, when Bateson obtained additional financial support for this work, he invited Punnett to collaborate with him. The result was a partnership that lasted six years, yielded many advances in genetics, including the first recognition of autosomal linkage - and showed Punnett how useful the fowl could be for experimental investigations of heredity. 
It is no exaggeration to say that Professor Punnett's studies provided the broad foundation on which now stands our present knowledge of heredity in the fowl. For one thing, those studies extended over 54 years. For another, they dealt with genetic variations in form and in function, with simple mutations, with polygenic characters, and with differences of almost every kind that distinguish breeds, varieties, individuals and sexes.

When Punnett joined forces with William Bateson in 1904, the latter had already demonstrated that rose and pea combs were both dominant to single ones. In the following year, the two investigators suggested that the walnut comb (of Malays) results from the interaction of the dominant genes $R$ and $P$, and that single-combed birds must lack both. Proof followed in 1906 and 1908, and the walnut combs now provide in many a text a familiar example of the interaction of complementary genes. At the same time, the genetic bases were worked out for duplex combs, for the trifid combs of Silkies and for the peculiar combless condition of the rare Dutch Bredas.

Another problem (far more mysterious in 1905 than others of the same kind now) was cleared up with the evidence (reported in 1906) that all Blue Andalusians are heterozygotes. These famous fowls, with their black and blue-splashed-white homozygotes, still provide in our texts a standard example of incomplete dominance and of preference by the fancier for a heterozygote that cannot breed true.

Punnett's study (with Bateson) of the black skin of the Silky fowl revealed that the condition is inhibited by the sex-linked gene now designated as $I d$. Subsequent experiments, some of them in collaboration with P. G. Bailey and others with Michael Pease, elucidated such structural variations as feathered shanks, polydactyly and the hen-feathered cocks characteristic of Sebright Bantams and some Campines. The report on polydactyly, although modestly entitled only "Genetic studies in Poultry. VII Notes on Polydactyly" covered extensive data of many years. It provided conclusive evidence of a dominant gene inducing that condition, and of its irregular manifestation and asymmetrical expression in some matings.

It was inevitable that variations in colour of the plumage should be investigated. Down through the years came reports of genetic studies (with Pease) of the autosomal barring of Campines, the gold Barred Rock, and of pied plumage.

Punnett's interest in sex-linked genes, particularly those causing barring $(B)$ and the $S-S$ alleles responsible for the silver and gold varieties of several breeds, led to his very practical advocacy (in 1919) of the use of interbreed crosses that permit recognition of male and female chicks at hatching by the colour or markings of the down. Seven years later, the use of the three pairs of sex-linked characters for that purpose was carefully explained in a special publication of the Ministry of Agriculture. It was illustrated with two colour plates. As that was long before the age of colour photography, the plates were prepared from water-colour drawings done from chicks provided by various breeders.

Punnett knew, however, that (in the "twenties) purebred chickens were respectable, but crossbreds were considered by many poultrymen to be almost as disgraceful as the bar sinister in man. If he could make sex-linked genes identify the sexes in some pure breed, so that no crossing would be necessary, they could be much more widely used. Further studies in this field led to his development by 1930 of the auto-sexing Cambar. The new breed was synthesized by transferring the gene $B$ from Barred Rocks to Golden Campines. The latter provided a plumage in which the difference between $B B$ males and $B$-females was much more evident than in pure Barred Rocks. Ten years later came his Legbars, an auto-sexing breed that resulted from introducing $B$ to Brown Leghorns.

These auto-sexing breeds would have had a great value to the poultry industry had it not been for the discovery and widespread utilization in the 1930's of the Japanese method for distinguishing the sexes of newly hatched chicks by examination of the cloaca.

Punnett's contribution to our knowledge of polygenic inheritance in the fowl is not always appreciated as much as it should be. After Nilsson-Ehle's elucidation of the operation of "multiple factors" in wheat, Punnett and Bailey made a cross between comparatively large (Hamburgh) and small (Sebright) breeds to study the subsequent segregation of body size. Distribution of weights in the $F_{2}$ generation conformed nicely to the normal curve expected according to the Nilsson-Ehle hypothesis.

Similar studies of the colour of egg-shells in two different crosses led to the conclusion that brown or tinted shells result from the action of a major gene for colour and an undetermined number of genes with minor effects. 
A more important study of a quantitative character was Punnett's investigation (reported in 1930) of the genetic basis then supposed responsible for differences in egg production. Up to that time most workers in that field had attempted to fit variations in ability to lay into a few arbitrary classes which permitted assignment of simple Mendelian ratios to observed segregations of good, poor, or indifferent layers. An underlying tenet of all orthodox faith since 1912 was belief in Pearl's sex-linked gene, $L_{2}$, which supposedly occurred only in the more prolific birds.

Reasoning that any such gene should show some linkage with other sex-linked genes, such as $B$ and $S$, which were by then known to lie some distance apart, Punnett made crosses between good layers that carried $B$ and $S$ and poor layers having the recessive alleles of those two genes, and then tested in back-crosses for linkage of prolificacy with $B$ and $S$. None was found; the 18 year reign of $L_{2}$ was ended.

One of Punnett's most useful contributions in poultry genetics was his book Heredity in Poultry published in 1923. In his usual pellucid style, it combined an exposition of simple principles of genetics with a concise survey of knowledge of inherited variations and secondary sex characters in the fowl. The widely scattered literature in that field was listed in a useful bibliography, and, more important, it was carefully digested and evaluated in the light of his own extensive research. It was thus easy for readers to see not only what facts had been established but also what remained to be done. The book was illustrated with 12 plates, five of them in colour.

Punnett's interest in sex-linked genes led to his very useful consolidation (in 1940) of all linkage data then reported for the sex chromosomes along with his own extensive data accumulated from 1927 to 1939 . From these figures he compiled a map showing the tentative arrangement of seven genes in that chromosome. Particularly useful was his ingenious solution of a problem that had bothered early investigators, i.e. how to classify chicks from tests for linkage of $B$ with $I d$, the inhibitor of dermal melanin. The difficulty arises from the fact that in growing birds and adults, both genes eliminate melanin from the dermis.

Punnett observed, however, that $B$ does not do so in newly hatched chicks, while $I d$ does. By classifying at hatching and again when the chicks were older, he was able to show that, contrary to the conclusions of earlier workers, cross-overs do occur between these two genes, and that their loci are 9.3 units apart.

As his studies brought him into contact with poultry breeders, Punnett's interests broadened to include an interest in their problems. He acquired a fine collection of old poultry books, and, moveover, knew their contents as well as their covers. An annotated list of such books was published (with E. C. Lewer) in 1930, and excerpts from several of them were presented (with delightful comments) in Poultry Industry between 1941 and 1958.

Among Punnett's other useful contributions to poultry genetics was his report of the first sex-linked character known in the duck-a dilution of the colour of the down. Another was his investigation of the blue egg-shells produced by the Araucana fowls of Chile. These he found to be caused by a dominant autosomal gene. When it intereacts with genes that would otherwise induce brown eggs, an olive green colour results. Punnett pointed out that such a blue-egg gene could account for the polychromatism of shell colour in eggs laid by some pheasants.

While the studies of this pioneer may not seem important to the youthful geneticist of to-day, with his government grant for research, his corps of technicians to do the work and a statistician in the adjoining office to provide impressive statistical analyses, let us not forget that Punnett and his co-workers were their own poultrymen. They managed the incubators, pedigreed the chicks, and fed them. In his delightful "Early Days of Genetics" written in 1950, Punnett gave us a glimpse of his beginnings with chickens in 1904:

"The set-up was primitive for money was scarce. The poultry occupied a small paddock split up into two dozen little pens. There were several incubators in a bedroom upstairs though this had soon to be given up since it was requisitioned for the little boys' governess. The chicks were reared in movable brooders along the garden paths. It was not a very satisfactory arrangement for, in a wind, one of them occasionally caught fire, and there was an end to that hatch. We had only oil, which meant much work in filling the various receptacles and cleaning the wicks. Every afternoon one of us went out collecting and marking the eggs from various pens. We had no trap nests but soon became adepts at spotting the eggs

laid by each particular hen...". 
Apart from fires in the brooders, there were other interesting diversions. Dr. A. G. Cock, of the University of Southampton, who, from his collaboration with the late Michael Pease, had inherited the Bateson-Punnett notebooks, has kindly sent me copies of some of the more unusual pages. Concerning one dubious character, the record reads: "3-10. W.B. bets R.C.P. 2 to 1 in crowns this a of. The outcome, alas, was not recorded, but for another bird the full story was told:

"2-7 no pigt. Crest coming.

24-7 W.B. bets R.C.P. 1/- that this bird is a $\hat{o}$. Taken!

22-8 won by R.C.P. Pd. Crest".

Collaboration with Bateson led Punnett to become interested in variation in sweet peas, but it was his innate curiosity, the questing mind of a naturalist, that prompted him to study heredity and variation in species ranging all the way from butterflies to man. His studies of mimicry in butterflies led to publication of his book on that subject in 1915 . Other investigations included coat colour in rabbits (particularly the Dutch and English patterns) body size in that same species, heredity in African marigolds, Mendelian inheritance in hybrid warblers, eye colour in man, various aspects of sex determination, and the inheritance of egg-colour in parasitic cuckoos. Some idea of the versatility of his curiosity can be had by glancing through the complete list of his publications as given by Crew (1967).

Punnett's Mendelism, published in 1905, was the first text on genetics. It went through seven editions in English, and was translated into seven foreign languages. It had a great influence on the understanding and development of genetics. That was not just because it was the first in the field, but, rather because it was written with great clarity.

Together, Bateson and Punnett founded the Journal of Genetics in 1911, and edited it jointly for 15 years. After Bateson's death in 1926, Punnett continued as editor for another 20 years. He also edited Scientific papers of William Bateson (two volumes) published in 1928

In addition to all his other activities, Punnett maintained an active interest in the poultry world. He participated in five of the seven world's poultry congresses that were held up to the time of his retirement from Cambridge in 1940. After that retirement, he and Mrs. Punnett lived at Bilbrook, near Minehead, in Somerset, where he continued his investigations until a disastrous fire destroyed his facilities in 1955. His studies in that period included the genetic basis for cream plumage, and his final report, published in 1957, was about recessive black.

Punnett was a gentle sort of man, very kind, and very modest. When (in the 1940 's) I wrote to tell him that I was trying to grind out a worthy successor to his Heredity in Poultry and to ask permission to use illustrations from the Journal of Genetics, the outcome was a delightful correspondence which proved very valuable to me because nearly every letter asked "How is that book coming along?" Only those who have toiled long at a book know how necessary such friendly prodding can be!

Later on, when the finished product was in his hands and we met in Bilbrook to discuss it, I had a reward not mentioned in my contract with the publishers. During our correspondence, I had confessed to Punnett that I am an enthusiastic admirer of Blackmore's Lorna Doone, and had congratulated him on his privilege of living on the fringe of Exmoor whence he could easily sally forth to explore the Doone country. On the second day of my visit, along came the Punnetts in an enormous car, rented for the day, and complete with liveried chaffeur, in which I was whisked away for an unforgettable day.

The tour began with Dunster Castle, took us up Porlock Hill, all over Exmoor and the Doone country, and eventually to a delightful tea-room in Withypool, where (by special arrangement made in advance) the trans-Atlantic visitor was treated to tea with strawberry jam and some of the clotted cream for which that region is famous. Such rewards are remembered better than royalties.

On another visit, after I had sent him a later book, he said: "You have given me a book that weighs four pounds. In return, I give you one that weighs four ounces." It was a first edition of his Mendelism*"

Punnett's innate curiosity and his zeal for scientific analyses are well illustrated by three of his activities at different stages of his career. When faced (about 1901) with an operation for appendicitis, he arranged to have the offending organ properly preserved so that he could later section it to determine whether or not there was any truth in a theory then prevalent that appendicitis might be caused by small worms. No support for the notion was found.

Seven years later, after he had given an address in London on Mendelian 
heredity in man, critics demanded to know why, if brown eyes are dominant to blue ones, the population did not become all brown-eyed. He realized that with continuous segregation of blues from heterozygous browns, there must be some equilibrium of the two types in the population. On his return to Cambridge, he put the problem to a fellow-cricketer, G. H. Hardy, who was a mathematician. The result was the now well-known formula, $p^{2}+2 p q+q^{2}$, for the proportions of $A A, A a$ and $a a$ individuals in a population carrying $A$ and $a$. Because the same formula was recognised independently at about the same time by Weinberg in Germany, it is now known as the Hardy-Weinberg Law.

Many years later, when the increasing infirmities of advancing years had somewhat circumscribed his activities, but had by no means laid low the spirit of enquiry, he combined that spirit with a favorite pastime,-playing bridgeto see how closely the cards in many hands conformed to the expected random distribution. A report on the first 10,000 hands was published in Bridge Magazine in 1956 , to be followed two years later by another called simply "A further 10,000 hands".

So passed Punnett, but his name and his contributions to knowledge live on. F. B. HUTT, Cornell University, Ithaca, New York.

* This copy is now in the library of the University of Guelph, in Canada.

\section{REFERENCES}

(A complete bibliography of Punnett's publications is given by Crew, 1967).

CREW, F. A. E. (1967). Reginald Crundall Punnett, 1875-1967. Biograph. Memoirs Fellows Roy. Soc. 13, 326-326. See also Genetics, 58, 1-7 (1968).

PUNNETT, R. C. (1923). Heredity in Poultry. XI\%pp. 1-204. London, Macmillan and Co., Ltd. PUNNETT, R. C. (1950). Early days of genetics. Heredity, 4. Pt. I: 1-10.

\section{World Import Duties on Eggs and Egg Products}

Dr. W. Bruce Silcox, Dairy and Poultry Division, Foreign Agricultural Service, U.S.D.A., Washington, D.C., U.S.A., is author of an 81 page bulletin entitled "World Import Duties and Other Entry Charges on Eggs and Egg Products". This Bulletin published in October 1969 is No. 137 Foreign Agriculture Report, U.S. Department of Agriculture.

This report presents the entry costs imposed by 114 countries as well as the U.S.A. import duties. Tables of import duties and other entry charges are given for the following products: Shell eggs, Frozen whole eggs, Frozen yolks, Frozen egg albumin, Dried whole eggs, Dried yolks and Dried albumin.

The average entry charges from July 1967 through June 1968 were as follows; based on the cureent U.S. dollar exchange rate:

Entry Charges

Shell eggs - 19.99 cents per dozen

$\begin{array}{lllllll} & & & & & & \\ & . & . & . & 102\end{array}$

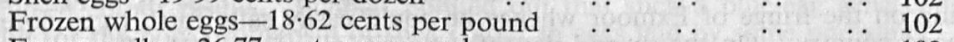

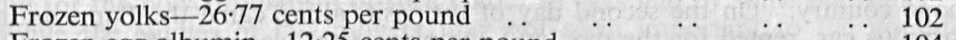

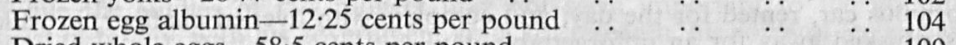

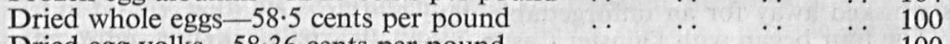

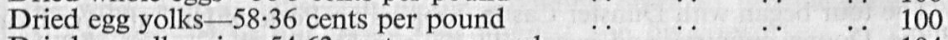

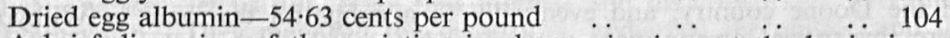

A brief discussion of the variation in charges is given at the beginning and illustrated by frequency distributions of the numbers of countries having entry charges at each price range.

\section{Progress Report from India 1968-69}

Dr. R. M. Acharya and his staff of the Department of Animal Breeding, Punjab Agricultural College, Hissar (Haryana), India, have prepared, in mimeograph form, two annual progress reports: 1 . Collection and Evaluation of Native Fowl Germ Plasm (P.L. 480 Project, 2. Breeding of Chickens to Develop Suitable Hybrids for Broiler Production (I.C.A.R. Scheme). 